УДК 37:001.12/18

(C) Золотухіна С. Т., Фазан В. В., Макаренко В. В., 2021 p.

http://orcid.org//0000-0002-3535-5974

http://orcid.org//0000-0002-9823-3704

http://orcid.org//0000-0002-8651-2802

DOI $10.34142 / 23128046.2021 .50 .06$

C. T. Золотухіна

В. В. Фазан

В. В. Макаренко

\title{
ТРАДИЦІї ТА НОВАЦІї У ПЕДАГОГІЧНІЙ ДІЯЛЬНОСТІ
}

У статті на основі аналізу наукової літератури, досвіду роботи у закладі вищої освіти, результатів досліджень педагогічного спрямування розкрито взаємозв'язок традииій $і$ інновачій у педагогічній діяльності. Підкреслено, що підготовка фахівців нової формації залежить від органічного творчого поєднання традииійних та інноваційних форм, методів навчання і виховання в освітньому процесі. Розкрито суть традицій як перевірений часом педагогічний досвід, як механізм накопичення специифічних норм, иінностей, прикладів постановки $i$ розв'язання проблем, які дозволяють за певних умов отримати гарні результати.

Підкреслено, щуо педагогічна традиція як складне явище вміщує багато компонентів, виконує різні функиії, має різні види $і$ знаходить свій вираз у значній кількості педагогічних форм, засобів, технологій, методик.

У статті показано ставлення видатного украӥнського педагога В. О. Сухомлинського до педагогічних традииій як скарбнииі, «куди кожне покоління кладе свій маленький коштовний внесок». У тексті наведено аргументи на користь реалізачиї інновачійних заходів у педагогічному процесі, а саме: інтенсивний розвиток IKT, інтеграчійних процесів; особливості сучасної студентської молоді; зміна ролі і функцій викладача вищої иколи.

Розкрито місие і значення інновацій у діяльності викладача, зокрема, підкреслено їх роль у забезпеченні діяльної позииії суб'єктів освітнього процесу, у вивченні досвіду обговорення проблем, набутті самостійності, формуванні активно-позитивної мотивачії, спрямуванні особистісного розвитку, сприянні розвитку пізнавального інтересу, введенні здобувачів у дослідницьку сферу.

На основі аналізу наукової літератури узагальнено погляди дослідників щодо вагомого «внеску» інновачійності в стимулювання академічної $i$ професійної мобільності здобувачів на основі самоосвіти, їх изннісних орієнтирів і життевих смислів. 
У статті представлено у систематизовану вигляді вимоги до викладача вищзӧ школи, як головного реалізатора інновацій у професійній діяльності. Підкреслено, щзо викладач, який здатний творчо, результативно працювати, бути конкурентоспроможним в умовах сьогодення, виступає «творием», ініціатором конкретних нововведень, може мати статус інноваційної особистості. Подано різні точки зору науковців щуодо визначення «інноваційної особистості».

Отримано висновок про доцільність розумного поєднання традиційних і інноваційних форм та методів, про процес взаємоперетворення інновацій у традиції та народження нових інновацій із традицій, про їхній взаємозв'язок і взаємодоповнення.

Ключові слова: традиціі, інновації, взаємозв'язок, досвід, вищза школа, здобувач вищьої освіти, інноваційний викладач.

Zolotukhina S. T., Fazan V.V., Makarenko V. V. Traditions and innovations in pedagogical activity. Based on the analysis of scientific literature, work experience in the higher educational institution and the results of pedagogical research, the relationship of traditions and innovations in pedagogical activity is revealed in the article. It is emphasized that training of specialists of the new formation depends on the organic creative combination of traditional and innovative forms, methods of training and upbringing in educational process. The essence of traditions is defined in the article. They are time-tested pedagogical experience, a mechanism of accumulation of specific norms, values, examples of formulating and solving problems, which allow to obtain good results under certain conditions.

It is emphasized that pedagogical tradition as a complex phenomenon includes a lot of components, performs various functions, has different kinds and is reflected in a significant amount of pedagogical forms, means, technologies and techniques.

The article reveals great Ukrainian educator $V$. O. Sukhomlynskyi's attitude to pedagogical traditions as treasure house "where all generations put their little precious contribution". The article presents arguments in favour of implementation of innovative activities in pedagogical process, namely: intensive development of ICT and integration processes, specific features of modern student youth, change of role and function of higher school lecturer.

The place and significance of innovations in lecturer's activity are revealed in the article. For instance, the focus is on their importance in ensuring the active position of the subjects of educational process, in gaining the experience of discussing problems, forming learning independence, active-positive motivation, directing personal development, promoting the development of cognitive interest, introduction of applicants into research field.

Based on the analysis of scientific literature, the researchers'views on significant "contribution" of innovation in stimulating applicants' academic and 
professional mobility on the basis of self-education, their values and meanings of life are generalized.

The article presents in a systematic form the requirements for higher school lecturer as the main implementer of innovations in professional activity. It is emphasized that a lecturer, who is able to work creatively and effectively and to be competitive in today's conditions, acts as "a creator", an initiator of specific innovations etc., can have the status of an innovative person. Scholars' different points of view on the definition of "innovative personality" are presented.

The authors make a conclusion on the expediency of a reasonable combination of traditional and innovative forms and methods, process of interconversion of innovation in tradition and emergence of new innovations from traditions, their interrelation and complementarity of each other.

Keywords: traditions, innovations, relationship, experience, higher school, applicant for higher education, innovative teacher.

Вступ. Відомо, що саме суперечності є рушійними силами прогресу у всіх сферах суспільного життя. В основі розвитку педагогічної науки i практики, як свідчить аналіз наукової літератури, результатів досліджень психолого-педагогічного спрямування, досвіду роботи у вищій школі, також лежить низка суперечностей, зокрема між використанням традицій i інновацій у педагогічному процесі.

Зазначене все частіше стає предметом педагогічних дискусій, наукових розвідок, змістом науково-практичних конференцій (Sukhomlynskyi, 1977). Так, вивчення питання взаємозв'язку традицій та інновацій, обгрунтування інноваційних заходів, методик, технології здійснювали О. Дубасенюк, Н. Кичук, І. Коновальчук, Д. Алфімов, І. Дичківська, В. Хилинець, О. Попова, В. Євдокимов, І. Прокопенко та інші. Проте потребує розкриття і визначення переваг кожної з сторін визначеної суперечності.

Мета та завдання. Мета статmі - на основі аналізу науковопедагогічної літератури з'ясувати ступінь взаємозв'язку традицій та інновацій у діяльності викладача вищої школи в сучасних умовах.

Методи дослідження. В процесі наукового пошуку використано такі методи наукового пізнання, як: аналіз науково-педагогічної літератури, вивчення досвіду роботи викладачів вищої школи, систематизація результатів педагогічних розвідок.

Результати. Сучасний етап розвитку суспільства характеризується динамічними, глобальними трансформаціями всіх сторін суспільного життя, посиленням тенденції утворення європейського освітнього простору, швидким розвитком інформаційних, цифрових технологій. 
Вищезазначене вимагає підготовки компетентних, мобільних, самодостатніх фахівців, які мають активно включатися в складну систему суспільних взаємовідносин і які здатні самостійно оволодівати системою грунтовних знань, критично їх осмислювати, творчо використовувати у подальшій професійній діяльності, постійно навчатися упродовж життя, а також розв’язувати нестандартні задачі, приймати швидкі рішення тощо.

Одним із напрямів реформування підготовки майбутніх фахівців нової формації, на наше переконання, є органічне і творче поєднання традицій та інновацій в освітньому процесі.

Сучасна тенденція запровадження інноваційних засобів і форм в освіту схвальна, але вона має ефективно реалізуватися на основі існуючих традицій. Саме традиції (від лат. Traditio - переказ) як механізм накопичення, збереження і трансляції наукового, педагогічного досвіду, специфічних норм, цінностей, зразків постановки і рішень проблем, вміщують у собі багато компонентів, виконують численні функції, знаходять вираз у великій кількості форм і способів.

Так, видатний український педагог В. Сухомлинський підкреслював, що «без звичок і традицій ... не буває справжньої свободи особистості» (Sukhomlynskyi, 1977). Необхідно створювати і зберігати традиції, передавати їх від покоління до покоління як духовне надбання колективу, зазначав він. Традиції педагог порівнював із скарбничкою, куди кожне покоління складає свій невеликий коштовний внесок (Sukhomlynskyi, 1977).

Традиційними в школі В. Сухомлинського були: зустріч школярів з 5-6 річними дітьми, які через 1-2 роки прийдуть до 1 класу; свято першого i останнього дзвоника; урочисте вручення атестатів; зустріч випускників минулих років; свято матері; свято дівчат; свято пісні, птахів; рапорт друзям; день невідомого героя; зимове свято снігового містечка; трудові традиції, зокрема, - день першого снопа, свято першого хліба, благоустрій села тощо (Sukhomlynskyi, 1977).

Зазвичай у якості традицій виступають ідеї, обряди, форми, методи роботи тощо. Педагогічні традиції як перевірений часом досвід виховання, навчання, який за рахунок систематичного характеру навчання, впорядкованості логічно правильного подання матеріалу, організаційної чіткості, оптимального витрату ресурсів під час самостійного навчання дозволив у свій час отримувати високі результати.

Науковці О. Дубасенюк, К. Шабалкіна, Н. Кічук, Т. Федюшина, 3. Осіпова, Л. Ляшенко, Н. Уманець та інші, підкреслюючи роль і значення педагогічної традиції, виділяють і іï структуру, а саме: а) особистість, яка і визначає буття традицій у суспільстві, і яка є носієм педагогічної традиції; б) 
результат діяльності, суб'єктно-педагогічний досвід, що знайшов відображення в змісті педагогічної традиції; в) виховання, навчання, розвиток, формування особистості.

Отже, педагогічна традиція як сукупність того, що прийшло в спадок від одного покоління до другого, переосмислювалась, пристосовувалась до нових обставин, змінюючи свої функції і створюючи нову систему якостей, елементів.

Аналіз роботи у закладах вищої освіти свідчить, що педагогічна діяльність навіть у сучасних умовах не можлива без використання традицій (педагогічних, наукових, методичних). Існуючі упродовж століть структура уроку: опитування, повідомлення, вправи, самостійна робота, перевірка; організаційні форми навчання: фронтальні, групові, індивідуальні; методи навчання: вербальні, наочні, практичні, які мають бути переосмислені, пристосовані до нових обставин, змінять свої принципи, створять нову систему елементів, на наше переконання, не втратили і не втратять методичної цінності.

Однак, особливості розвитку науки, техніки, високі вимоги до фахівців будь-якої сфери вимагають, як зазначалось раніше, запровадження інновацій у педагогічну діяльність.

Це твердження посилюється, по-перше, потребою урахування особливостей віку студентської молоді. Студентський вік - це період формування активної творчої особистості, засвоєння соціального досвіду, період прагнення до прийняття самостійного вибору. Студентський вік - час прийняття рішень у різноманітних життєвих ситуаціях, засвоєння необхідних соціальних норм і цінностей, формування соціальних і пізнавальних мотивів $\mathrm{i}$ інтересів. Студентський період - це така життєва стадія, яка вимагає від молоді активних дій, задоволення потреби в творчості, інноваційності, креативності тощо.

По-друге, застосування інновацій у педагогічну діяльність зумовлено, як свідчить аналіз педагогічної, методичної літератури та досвіду роботи викладачів вищої школи, докорінною зміною цілей освіти, широкою комп’ютеризацією освітнього процесу, що вимагає формування у майбутніх фахівців професійної, соціально-наукової мобільності, розвитку творчого потенціалу особистості, а також почуття власної гідності, працелюбства, відповідальності.

Інновація (від лат.) - «оновлення, зміна», у педагогіці - нововведення, що поліпшує хід і результати педагогічного процесу. Інноваційні педагогічні технології - це «цілеспрямоване, систематичне й послідовне впровадження в практику оригінальних, новаторських способів, прийомів педагогічних дій і 
засобів, що охоплюють цілісний навчальний процес від визначення його мети до очікуваних результатів у навчально-виховному процесі» (Dychkivska, 2004).

Вищезазначене спонукає викладача вищої школи шукати найкращі, оптимальні, ефективні, новітні способи, методики, технології викладання, організації освітнього процесу, стратегії навчання.

Відомо, що інноваційне навчання відбувається за рахунок використання активних (діяльнісна позиція здобувача освіти до викладача) й інтерактивних (співпраця здобувачів між собою) методів і форм.

Обов'язковою умовою забезпечення активності, інтерактивності у навчанні $\epsilon$ використання таких засобів (рольові, ділові ігри, кейс-стаді, коучінг, мозковий штурм, ІКТ тощо), які мають творчий характер.

Отже інновації в педагогічному процесі означають як введення нових елементів у зміст, мету, методи, організацію діяльності викладача і здобувача, так і запровадження нової системи, методики, технології в цілому 3 метою підвищення його ефективності. Наприклад, інноваційність на ОНП передбачає забезпечення варіативності навчальних дисциплін з урахуванням різних спеціальностей здобувачів, посилення мотивації до навчання в аспірантурі, розвиток здатності рефлексії, стимулювання креативності і творчості.

3'ясовано, що інновації в педагогічній діяльності виникають як стихійно, під впливом ситуативних вимог, так і як продукт ретельного обміркування особистістю і колективом. Отже, інноваційну діяльність слід розуміти як діяльність, засновану на рефлексії власного і колективного досвіду.

Інноваційність в освітньому процесі забезпечує діяльнісну позицію суб'єктів навчання; індивідуальний темп засвоєння інформації; вчить досвіду обговорення ситуацій, проблем, самостійності; формує активно-позитивну мотивацію; спрямовує особистісний розвиток; вводить здобувачів у дослідницьку сферу; сприяє розвитку пізнавального інтересу. Крім того інноваційність забезпечує, стимулює академічну і професійну мобільність здобувача, створює умови для розвитку особистості на основі самоосвіти, іiі ціннісних орієнтацій і життєвих смислів.

Інноваційність, на наш погляд, не слід розуміти тільки як запровадження новітніх форм і методів роботи викладача. Вона включає інтенсифікацію творчого процесу викладання, накопичення досвіду індивідуально-творчої, колективно-творчої діяльності, зміну відносин між суб’єктами педагогічного процесу, удосконалення системи самостійної 
роботи, контроль підвищення рівня методичної та технологічної культури викладачів.

У педагогічній літературі чітко визначено критерії інноваційності, якот: відкритість, особистісна орієнтація, технологічність, мобільність, творчість, демократизація життєдіяльності сучасного освітнього закладу (гуманізація, гуманітаризація, фундаменталізація, професіоналізація, культурологічний підхід).

Дослідники Л. Даниленко та Л. Клокар додають в якості ознак ще i новизну (абсолютну, локальну, умовну, суб'єктивну), оптимальність, яка сприяє досягненню високих результатів за найменших витрат часу фізичних, розумових сил; результативність, можливість творчого застосування в масовому досвіді. Науковцями також визначено етапи функціонування педагогічних інновацій: ознайомлення викладача 3 педагогічними інноваціями; поява зацікавленості, оцінка, апробація, інтуїтивне сприйняття.

По-третє, аналіз науково-педагогічної літератури та досвіду роботи викладачів різних закладів освіти дає підстави стверджувати, що виконання державних замовлень у напрямі підготовки майбутніх фахівців нової формації залежить від багатьох чинників, серед яких особистість викладача займає особливе місце.

Саме від нього в значній мірі залежить «реконструкція» педагогічного процесу у вищій школі, що передбачає, перш за все, зміну його функціональних ролей: «викладач - лектор - транслятор» на «викладачконсультант». Крім того, викладач має відповідати сучасним запитам, володіти комплексом здатностей: організаційних, предметних, методичних, технологічних, які забезпечують створення нової педагогічної етики, побудову творчо-продуктивного середовища, зокрема, постійне професійне та моральне самовдосконалення; володіння технологіями, методиками, механізмами набуття знань; реагування на постійні глобалізаційні зміни в суспільстві і освіті, творче проєктування індивідуальних планів здобувачів, запровадження в освітній процес інтегративних складових, інноваційних форм і методів. Зазначені якості, уміння, здатності, якими має володіти сучасний викладач, дозволяють віднести його до розряду «інноваційний» викладач.

Науковці Д. Алфімов, О. Дубасенюк, О. Ігнатович та інші зазначають, що інноваційна особистість - це «особлива якість людини, що набувається нею в інноваційному соціокультурному середовищі в процесі організації інноваційної діяльності та спілкування» (Alfimov, 2010; Dubaseniuk, 2009; Ihnatovych, 2007) 
Здатність до інновацій, як зазначає О. Ігнатович, стала умовою орієнтації людини у швидкозмінних і швидкоплинних світових процесах, умовою не тільки адаптації до них, а й власної життєтворчості. Так, за даними Л. Верещагіна, С. Занок та інших, 2,5\% сучасних педагогів $\epsilon$ ініціаторами інновації, 13,5\% - ті, хто першими сприймають інновації та активно їх упроваджують; $34 \%$ викладачів характеризуються «поміркованим» ставленням до інновацій; $34 \%$ - повільно реагують на зміни і не поспішають їх сприймати; 16\% - консерватори, ті, хто не хоче і не може приймати інновації.

Отже, інноваційна педагогічна діяльність - це така діяльність, у процесі якої створюється новий своєрідний продукт, котрий виявляється у формуванні цінностей, якостей, ставлення, потреб, здатностей у майбутнього фахівця, які відповідають сучасним вимогам і дозволяють їм повноцінно функціонувати в освітньому сучасному просторі.

Така особистість, за твердженням О. Ігнатович, має особливі ознаки:

- інноваційний характер спілкування;

- інноваційна спрямованість (потреби, мотиви, цінності);

- інноваційні риси характеру (інноваційність, креативність, відповідальність, рішучість);

- усвідомлення себе як носія інноваційної культури;

- інноваційний інтелект (готовність до подолання інерції мислення, уміння генерувати нові нестандартні ідеї) (Ihnatovych, 2007).

Отже, інноваційний викладач - це такий викладач, який виступає «творцем, модифікатором конкретних нововведень, володіє широкими можливостями, має необмежене поле науково-педагогічної діяльності, характеризуються творчою активністю» (Alfimov, 2010; Dubaseniuk, 2009; Ihnatovych, 2007).

Обговорення. Педагогічна діяльність за своєю суттю складана, суперечлива, гнучка i, з одного боку, неможлива без опори на традиції, на те, що визнано і знайшло підтвердження в досвіді суспільства, освітнього закладу, особистості. 3 іншого, - розвиток освіти вимагає постійної реконструкції, реформації змісту, форм, методів, засобів, технологій, методик навчання і виховання.

Висновки. Таким чином, доцільність взаємозв'язку традицій та інновацій у практичній діяльності вцілому не викладає сумніву. Важливою умовою виступає урахування їх збалансованностей і взаємозв'язку:

$\checkmark$ потрібно розумно поєднувати традиційні форми і методи навчання 3 інноваційними;

$\checkmark$ існує процес взаємоперетворення інновацій в традиції та народження нових інновацій з традицій;

$\checkmark$ сучасне життя висуває свої вимоги і вимагає активно використовувати педагогами інноваційні технології в освітньому процесі. Саме їх 
застосування здатне забезпечити єдність освітніх, розвиваючих i виховних функцій;

$\checkmark$ потрібно, щоб інноваційні та традиційні методи навчання були у постійному взаємозв’язку і доповнювали один одного.

\section{ЛІТЕРАТУРА:}

Алфімов Д. В. Інноваційна освітня система: шляхи відродження. Педагогічні інноващії: iдеї, реалії, перспективи: Зб. наук. пр. К.: Логос, 2010. С. 158-160.

Дичківська І. М. Інноваційні педагогічні технології: навч. посіб. К.: Академвидав, 2004. $352 \mathrm{c}$.

Дубасенюк О.А. Інноваційні освітні технології та методики в системі професійної підготовки: Монографія. Житомир: Вид-во ЖДУ ім. І. Франка, 2009. С. 14-47.

Ігнатович О. М. Психологічна структура динаміки інноваційної діяльності педагогічних працівників. Педагогічний процес: теорія і практика: зб. наук. пр. К., 2007. Вип. 2. C. 198-208.

Коновальчук I. I. Інноваційне середовище як засіб розвитку інноваційної компетентності педагогів загальноосвітніх закладів. Вісник Житомирського державного університету імені Івана Франка. Педагогічні науки. Житомир, 2014. Вип. 4 (76). С 62-66.

Сухомлинський В. О. Вибрані твори у 5 томах. К. : Видавництво «Радянська школа», 1977, T1.

Традиції та інновації в сучасній педагогічній діяльності: європейський вимір. Зб. наук. праць за матеріалами наук.-практ. конф. Ізмаіл.: РВВ ІДГУ, 2017. 146 с.

\section{REFERENCES:}

Alfimov, D. V. (2010) Innovatsiina osvitnia systema: shliakhy vidrodzhennia. [Innovative Educational System: Revival Ways]. Pedahohichni innovatsii: idei, realii, perspektyvy: Zb. nauk. pr. K.: Lohos, S. 158-160(inUkrainian).

Dychkivska, I. M. (2004) Innovatsiini pedahohichni tekhnolohii [InnovativePedagogicalTechnologies]: navch. posib. K.: Akademvydav, 352 s. (inUkrainian).

Dubaseniuk, O. A. (2009) Innovatsiini osvitni tekhnolohii ta metodyky v systemi profesiinoi pidhotovky [Educational Technologies and Methods in Professional Training]: Monohrafiia. Zhytomyr: Vyd-vo ZhDU im. I. Franka, S. 14-47 (in Ukrainian).

Ihnatovych, O. M. (2007) Psykholohichna struktura dynamiky innovatsiinoi diialnosti pedahohichnykh pratsivnykiv. [Psychological structure of the dynamics of innovative activity of pedagogical workers]. Pedahohichnyi protses: teoriia i praktyka: zb. nauk. pr. K., Vyp. 2. S. 198-208 (in Ukrainian).

Konovalchuk, I. I. (2014) Innovatsiine seredovyshche yak zasib rozvytku innovatsiinoi kompetentnosti pedahohiv zahalnoosvitnikh zakladiv. [Innovative environment as a means of developing innovative competence of educators of general educational institutions]. Visnyk Zhytomyrskoho derzhavnoho universytetu imeni Ivana Franka. Pedahohichni nauky. Zhytomyr, Vyp. 4 (76). S. 62-66(in Ukrainian).

Sukhomlynskyi, V. O. (1977) Vybrani tvory u 5 tomakh. [Selected works in 5 volumes]. K. : Vydavnytstvo «Radianska shkola», T.1 (in Ukrainian).

Tradytsii ta innovatsii v suchasnii pedahohichnii diialnosti: yevropeiskyi vymir. [Traditions and innovations in modern pedagogical activity: European dimension]. (2017) Zb. nauk. prats za materialamy nauk.-prakt. konf. Izmail: RVV IDHU, 146 s.(in Ukrainian). 
ORCID: https://orcid.org/0000-0002-35355974, доктор педагогічних наук, професор, професор кафедри освітології та інноваційної педагогіки, Харківський національний педагогічний університет імені Г. С. Сковороди, вул. Валентинівська, 2, м. Харків, Україна,

e-mail: kaf_pedagogik@ukr.net

\section{Фазан Василь Васильович:}

ORCID: $\quad$ https://orcid.org/0000-0002-98233704, доктор педагогічних наук, професор, професор кафедри загальної педагогіки та андрагогіки, Полтавський національний педагогічний університет імені В. Г. Короленка, вул. Остроградського, 2, м. Полтава, Україна, 36000

e-mail: Fazanvv@gmal.com

\section{Макаренко Валентина Володимирівна}

ORCID: https://orcid.org/0000-0002-86512802, викладач-методист, Харківський радіотехнічний коледж, вул. Сумська, 18/20, м. Харків, Україна, 61057

e-mail: himiy2020@gmail.com
ORCID: https://orcid.org/0000-0002-35355974; Dr. hab. in Pedagogy, Professor, Professor of the Department of Educology and Innovative Pedagogy, H. S. Skovoroda Kharkiv National Pedagogical University, Valentynivska Street, 2, Kharkiv, Ukraine, 61168

e-mail: e-mail: kaf_pedagogik@ukr.net

\section{Fazan Vasyl Vasylovych:}

ORCID: https://orcid.org/0000-0002-98233704; Dr. hab. in Pedagogy, Professor, Professor of the Department of General Pedagogy and Andragogy, V. G. Korolenko Poltava National Pedagogical University, Ostrohradskoho Street, 2, Poltava, Ukraine, 36000

e-mail: Fazanvv@gmal.com

\section{Makarenko Valentyna Volodymyrivna:}

ORCID: https://orcid.org/0000-0002-86512802; Teacher-Methodist, Kharkiv Radio Technical College, Sumska Street, 18/20, Kharkiv, Ukraine, 61057

e-mail: himiy2020@gmail.com

Цитуйте цю статтю як: Золотухіна С. Т., Фазан В. В., Макаренко В. В. Традиції та новації у педагогічній діяльності.Теорія та методика навчання та виховання. 2021. № 50. C.65-74.

DOI: $10.34142 / 23128046.2021 .50 .06$

Дата надходження статті до редакції: 01.04.2021 p.

Стаття прийнята до друку: 14.04.2021 p. 